\title{
A DESMOID TUMOR IN PREGNANCY MIMICKING SUBCUTANEOUS ENDOMETRIOSIS; A CASE REPORT
}

\author{
GEBELIKTE NADIR GÖRÜLEN VE ENDOMETRIOMA ILE KARIŞABILEN DESMOID \\ TÜMÖR OLGU SUNUMU
}

\author{
Arif Aktuğ ERTEKIN (D), Ebru ÇÖĞENDEZ² D, Erhan UNCU³ (D), Erbil ÇAKAR² (D, Nazan TARHAN² (D, Habibe AYVACl² (D) \\ ${ }^{1}$ Aydın Adnan Menderes University, Faculty of Medicine, Department of Obstetrics and Gynecology, Aydın, Turkey \\ 2Zeynep Kamil Women and Children Diseases Traning and Research Hospital, Gynecology and Obstetrics Clinic, Istanbul, Turkey \\ ${ }^{3}$ Medical Park Hospital, Department of Surgery, Istanbul, Turkey
}

ORCID IDs of the authors: A.A.E. 0000-0003-2401-6616; E.Ç. 0000-0001-7062-3076; E.U. 0000-0001-9257-8229;

E.Ç. 0000-0001-6147-4240; N.T. 0000-0002-7571-4505; H.A. 0000-0002-8517-0556

Cite this article as: Ertekin AA, Cogendez E, Uncu E, Cakar E, Tarhan N, Ayvaci H. A desmoid tumor in pregnancy mimicking subcutaneous endometriosis; a case report. J Ist Faculty Med 2022;85(1):136-8. doi: 10.26650/IUITFD.806899

\section{ABSTRACT}

Desmoid tumors are benign non-metastasizing tumors. However, they may proliferate and infiltrate into adjacent tissues with high recurrence rates. Even though its etiology is unclear, a previous histories of trauma, surgery, pregnancy, use of medication containing estrogen, and having conditions such as familial adenomatous polyposis and Gardner syndrome can be regarded as contributing or risk factors.

Keywords: Pregnancy, desmoid tumor, abdominal subcutaneous endometriosis

\section{ÖZET}

Desmoid tümörler metastaz yapmayan benign tümörlerdir fakat etraf dokulara derin infiltrasyon yapabilir ve proliferasyon gösterebilirler, rekürens oranları yüksektir. Etyolojileri net olamamakla birlikte travma, geçirilmiş operasyonlar, gebelik, eksojen östrojen kullanımı, ailesel adenomatöz polipozis ve Gartner sendromu etken olabilmektedir.

Anahtar Kelimeler: Gebelik, desmoid tümör, karın duvarı ciltaltı endometriozis

\section{INTRODUCTION}

Desmoid tumors (DTs) are rare, benign tumors. They do not metastasize, however, they may cause serious morbidity and even mortality by infiltrating into adjacent tissues and organs with high recurrence rates. DTs constitute $0.1 \%$ of all tumors, and $3.5 \%$ of fibrous tissue tumors (1). Even though its etiology is unclear, a previous history of trauma, surgery, pregnancy, use of medication containing estrogen, having conditions such as familial adenomatous polyposis and Gardner syndrome can be regarded as contributing or risk factors (2). Subcutaneous and abdominal masses encountered during cesarean sections must be carefully evaluated and consulted about with a general surgeon and pathologist to avoid a possible need for adjuvant therapy and medicolegal problems.

\section{CASE REPORT}

A 32 year old pregnant woman presented with a right periumblical subcutaneous mass. The probable diagnosis was subcutaneous endometriosis because of a history of having previously had a cesarean section. In the first trimester ultrasound scan and thereafter, both ovaries were reported as normal. The patient had felt the mass for the first time at around the $26^{\text {th }}$ week of her pregnancy. At that time, an ultrasound exam revealed a heteroge-

Corresponding author/illetişim kurulacak yazar: aaertekin@gmail.com

Submitted/Başvuru: 04.01.2021 • Revision Requested/Revizyon Talebi: 17.02.2021 • Last Revision Received/Son Revizyon: 27.02.2021 • Accepted/Kabul: 30.03.2021 • Published Online/Online Yayın: 19.11.2021 
neous echogenic subcutaneous mass with smooth contours, resembling a subfascial intramuscular endometriosis. A planned cesarean section and concurrent excision of the mass was performed at the $39^{\text {th }}$ week of pregnancy. After closure of the uterine incision, the mass was completely excised to thesurgical tumor-free margin and the primary closure of the defect was achieved. Yellow and brown tissue discoloration was noticed on macroscopic evaluation of the cross-sectioned specimen. The histopathology revealed a benign proliferative, yet infiltrative tumor located in the striated muscle. The tumor was composed of fibroblast fibers with positive margin (Figure 1, 2, 3). No complication was observed postoperatively. Even though the patient was informed about the riskof recurrence, she did not accept adjuvant therapy. No recurrence developed during the 10 years follow-up period. Written permission was taken from the patient for this case presentation.

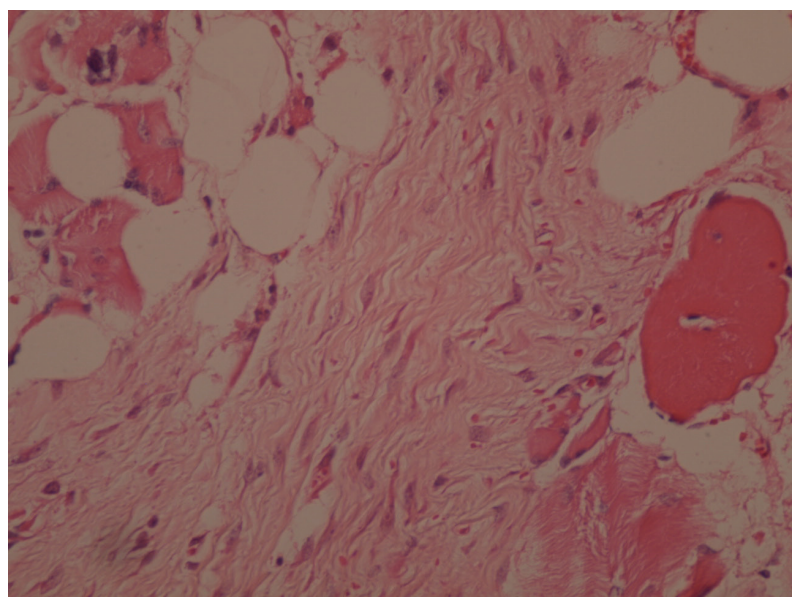

Figure 2: Microscopic closer view

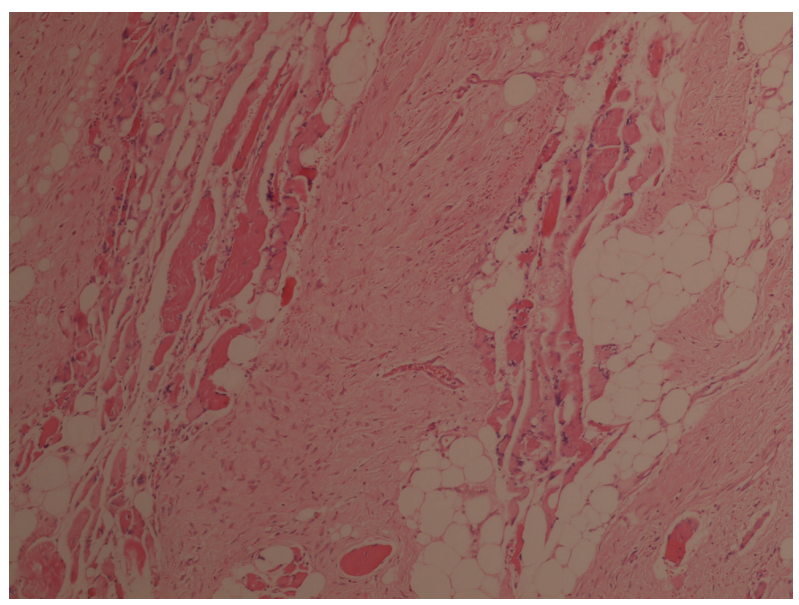

Figure 3: Microscopic view

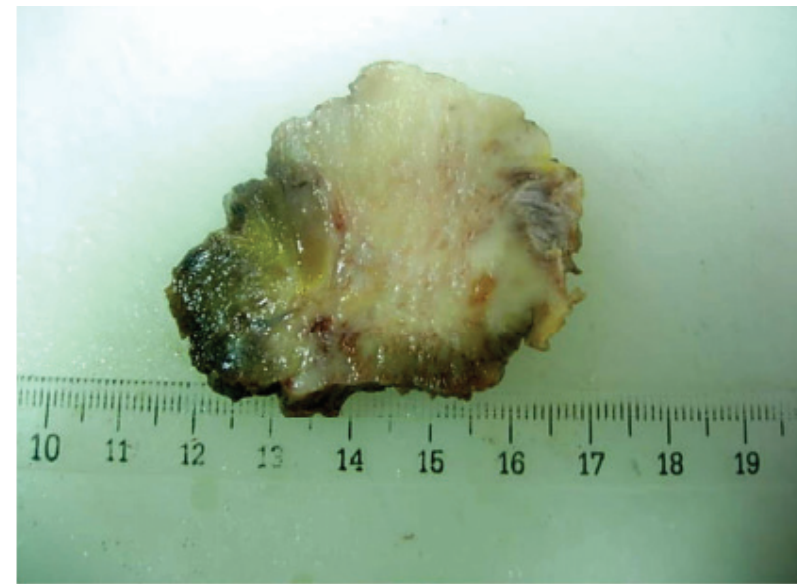

Figure 1: Macroscopic view

\section{DISCUSSION}

In the case presented here, the previous cesarean section may be counted as a risk factor and high levels of estrogen owing to pregnancy may be a contributing factor. In Lahat's case series of 16 patients, five of the DTs were diagnosed during or after delivery and two of them had infertility treatments (3). DTs are frequently located in the abdominal wall and abdominal cavity with an incidence of $37-50 \%$ and generally develop during pregnancy or postpartum period $(1,2,4)$. In patients with a history of having previously had a cesarean, abdominal wall endometriosis comes first in differential diagnosis (3). The incidence is higher in the reproductive years and tumors generally develop 2 to 5 years following a cesarean operation. Direct inoculation of endometrial cells onto the abdominal fascia and into subcutaneous tissues is believed to be in the etiology of abdominal wall endometriosis. Unlike abdominal wall endometrioses which are located at the superficial parts of the muscle and fascia, DTs are generally located adjacent to musculoaponeurotic tissues. Computerized tomography or magnetic resonance imaging (MRI) maybe helpful in differentiating between DTs andendometriosis.

A universally accepted management protocol for DTs does not exist but complete surgical resection with negative microscopic margins is generally accepted as the gold standard approach. Adjuvant therapies, such as radiotherapy, chemotherapy and antiestrogens (i.e. tamoxiphene) can be administered for the prevention of local recurrence in selected cases (1). Fiore et al. investigated the relationship between DTs in pregnancies and local recurrences. They found that pregnancy related DTs had a better prognosis than the sporadic DT cases and the local recurrence rate decreased after surgical resection (2). In their study on 426 cases with sporadic DTs, Salas et al. found that the microscopic examination of surgical mar- 
gins had no effect on prognosis, but age, tumor size and tumor location had significant effects on progression-free survival (5). They also found that an age younger than 37 years, a tumor size smaller than $7 \mathrm{~cm}$ and abdominal wall/abdominal cavity locations were good prognostic factors with low postoperative recurrence rates. Conservative management is generally recommended as initial approach only in selected cases with DTs due to high recurrence rates and the local aggressive behavior (5). Similarly, Kumar et al. and Le Roc'h et al. suggested conservative management of DTs in pregnancy, and leaving the surgical excision to the postpartum period $(6,7)$. Removal of assumed subcutaneous endometriosis during a cesarean section is recommended for pathologic confirmation or, as in our case, for finding out the true nature of solid masses. Pathologic diagnosis may also help in deciding the need for possible future adjuvant therapies in selected cases and may provide coverage for medicolegal loopholes.

In summary, DTs in pregnancy are usually located on the abdominal wall or in the abdominal cavity and expectant management strategy during pregnancy is a rational option. In cases with initial tumor size larger than $7 \mathrm{~cm}$ or progressive growth verified by appropriate imaging modality, surgical resection is a favorable as primary approach. DTs should be kept in mind among other differential diagnoses when abdominal masses are encountered during or right after pregnancy. Long term followup must be recommended due to high recurrence rates. In cases with smaller tumors $(<7 \mathrm{~cm})$, whichare located on the abdominal wall or in the cavity, close followup may be an appropriate option for the management even with positive margins. In the cases of extragenital endometriosis encountered during an operation, carefull evaluation of the abdominal cavity, especially the ovaries, have to be kept in mind. The decision to remove an ovarian endometrioma during surgery mainly depends on the symptomatic severity, stage and the fertility expectancy of the patient.
Peer Review: Externally peer-reviewed.

Author Contributions: Conception/Design of Study- A.A.E., E.Ç., E.Ç., N.T.; Data Acquisition- A.A.E., E.U.; Data Analysis/ Interpretation- A.A.E., E.Ç., H.A.; Drafting Manuscript- A.A.E., E.Ç., N.T., H.A.; Critical Revision of Manuscript- A.A.E., E.Ç., E.U., E.Ç.; Approval and Accountability- A.A.E, E.Ç., E.U., E.Ç., N.T., H.A.

Conflict of Interest: Authors declared no conflict of interest.

Financial Disclosure: Authors declared no financial support.

\section{REFERENCES}

1. Durkin AJ, Korkolis DP, Al-Saif O, Zervos EE. Full-term gestation and transvaginal delivery after wide resection of an abdominal desmoid tumor during pregnancy. J Surg Oncol 2005;89(2):86-90. [CrossRef]

2. Fiore M, Coppola S, Cannell AJ, Colombo C, Bertagnolli MM, George S. Desmoid-type fibromatosis and pregnancy. a multi-institutional analysis of recurrence and obstetric risk. Ann Surg 2014;259(5):973-8. [CrossRef]

3. Lahat G, Nachmany I, Itzkowitz E, Abu-Abeid S, Barazovsky E, Merimsky $O$, et al. Surgery for sporadic abdominal desmoid tumor: Is low/no recurrence an achievable goal? Isr Med Assoc J 2009;11(7):398-402.

4. Bertani E, Chiappa A, Testori A, Mazzarol G, Biffi R, Martella $S$, et al. Desmoid tumors of the anterior abdominal wall: Results from a monocentric surgical experience and review of the literature. Ann Surg Oncol 2009;16(6):1642-9. [CrossRef]

5. Salas S, Dufresne A, Bui B, Blay JY, Terrier P, RanchereVince $D$, et al. Prognostic factors influencing progressionfree survival determined from a series of sporadic desmoid tumors: A wait-and-see policy according to tumor presentation. J Clin Oncol 2011;29(26):3553-8. [CrossRef]

6. Kumar R, Lynch P. Large desmoid tumour causing unstable lie in pregnancy. J Obstet Gynaecol 2012;32(4):395-6. [CrossRef]

7. Le Roc'h A, Montaigne K, Leblond P, Subtil D, Boukerrou M. Desmoid tumour of the rectus abdominis muscle during pregnancy. J Obstet Gynaecol 2009;29(7):668-9. [CrossRef] 